\title{
Pengaruh Kualitas Auditor terhadap Manipulasi Aktivitas Riil
}

\author{
I Putu Sugiartha Sanjaya \\ Universitas Atma Jaya Yogyakarta \\ Jl. Babarsari No. 43 Yogyakarta, 55281 \\ E-mail: putu1970@mail.uajy.ac.id
}

\begin{abstract}
ABSTRAK
Tujuan penelitian ini adalah untuk menginvestigasi dampak kualitas audit pada manipulasi aktivitas riil. Kualitas audit diproksikan oleh afiliasi dengan auditor big four dan non-big four. Dalam artikel ini, auditor eksternal yang berafiliasi dengan big four memiliki kualitas yang lebih besar dalam hal spesialisasi dan reputasi dibanding auditor non-big four. Manipulasi aktivitas real adalah salah satu jenis manajemen laba. Studi ini menggunakan beberapa proksi untuk manipulasi aktivitas riil. Sampel dalam artikel ini adalah perusahaan-perusahaan manufaktur yang terdaftar di Bursa Efek Indonesia. Periode studi ini adalah tiga tahun. Penelitian ini membuktikan bahwa kualitas audit memiliki dampak negatif dan signifikan pada manipulasi aktivitas riil. Hasil ini mengindikasikan bahwa auditor reputasian dan spesialisasian dapat mencegah atau mengurangi manipulasi aktivitas riil.
\end{abstract}

Kata kunci: Kualitas auditor, manipulasi aktivitas riil, manajemen laba, big four, dan nonbig four.

\begin{abstract}
The objective of this paper is to investigate the impact of auditor quality on real activity manipulation. Auditor quality is proxied by affiliation with auditor big four or non-big four. In this paper, external auditor affiliating with big four has higher quality in specialitation and reputation than non-big four. Real activity manipulation is the one kind of earnings management strategy. This study uses some proxies for real activity manipulation. Sampel of this study is manufacturing companies listed in Indonesian Stock Exchange. Period of this study is three years. The result of this study is auditor quality has negative and significant impact on real acitivity manipulation. This result indicates that reputed and specialized auditor can reduce real acitivity manipulation.
\end{abstract}

Keywords: Auditor quality, real activity manipulation, earnings management, big four, and non-big four.

\section{PENDAHULUAN}

Tujuan paper ini adalah untuk menginvestigasi pengaruh kualitas audit terhadap manajemen laba riil atau manipulasi aktivitas riil. Kualitas audit diproksikan dengan auditor yang berafiliasi dengan big four dan tidak berafiliasi dengan big four (non big four). Manipulasi aktivitas riil ini akan terdeteksi dalam arus kas operasi, biaya produksi, dan biaya diskresioner. Manajer yang menggunakan manipulasi aktivitas riil dengan cara untuk meningkatkan arus kas operasi akan menyebabkan piutang dan arus kas operasi yang lebih berfluktuatif. Hal ini juga terjadi, jika manajer menggunakan biaya produksi dan biaya dis- kresioner untuk melakukan manajemen laba riil juga berdampak pada harga pokok penjualan suatu perusahaan. Penelitian ini menggunakan model Roychowdhury (2006) dalam pengukuran manajemen laba riil.

Paper ini merupakan pengembangan penelitian yang dilakukan oleh Sanjaya (2008) yang menemukan auditor berkualitas dapat mengurangi praktik manajemen laba. Manajemen laba dalam paper Sanjaya (2008) diproksikan dengan akrual diskresioner. Oktarina dan Hutagaol (2009) menemukan bahwa manajemen perusahaan memanipulasi aktivitas riil melalui aliran kas operasi. Ratmono (2011) menemukan bahwa manajer perusahaan melakukan manajemen laba riil bagi 
perusahaan yang memiliki batasan kinerja yang buruk. Manajer secara oportunistik menggunakan potongan harga untuk secara temporer menaikkan penjualan, melakukan produksi berlebihan (overproduction) untuk melaporkan kos barang terjual yang lebih rendah, dan pengurangan belanja diskresioner untuk meningkatkan laba yang dilaporkan. Sanjaya dan Saragih (2012) juga melaporkan manajemen laba akrual mempengaruhi manajemen laba riil.

Oktarina dan Hutagaol (2009), Ratmono (2011) dan Sanjaya dan Saragih (2012) mengindikasikan bahwa fenomena manajemen laba riil yang dilakukan oleh manajer di Indonesia adalah ada. Oleh karena itu, paper ini menginvestigasi apakah auditor berkualitas dapat mencegah atau mengurangi praktik manajemen laba dengan menggunakan aktivitas riil seperti penggunaan kebijakan diskon untuk meningkatkan jumlah penjualan sehingga target laba yang diinginkan dapat tercapai. Kedua, untuk memenuhi permintaan yang besar dari konsumen akibat kebijakan potongan harga menyebabkan perusahaan melakukan produksi yang besar sehingga ini dapat mengurangi kos barang terjual karena ada persediaan yang besar di akhir periode. Ketiga, manajer juga melakukan kebijakan atau diskresionernya untuk mengurangi pengeluaran-pengeluaran diskresioner untuk meningkatkan angka laba yang dilaporkan.

Praktik manajemen laba dengan aktivitas riil secara jelas akan berdampak pada penurunan keinformatifan laba karena praktik ini menurunkan kualitas laporan keuangan. Praktik memanipulasi aktivitas riil untuk memenuhi tujuan tertentu jelas mengurangi faithful representation dalam SFAC No. 8 (FASB, 2010) dan kredibilitas laporan keuangan.

Dalam hal demikian, penelitian ini menjadi penting untuk dilakukan karena hasil penitilian ini akan menemukan apakah kemampuan auditor sebagai penjamin atau assurance laporan keuangan dapat mencegah dan mengurangi serta mengidentifikasi praktik manajemen laba yang menurunkan kredibilitas laporan keuangan. Karena skandal-skandal akuntansi telah terjadi dalam beberapa tahun seperti kasus Enron yang melibatkan kantor akuntan publik ternama yaitu Arthur Andersen telah mempengaruhi kepercayaan publik pada laporan keuangan.

Dalam bagian berikutnya, paper ini menjelaskan tentang kajian teori dan pengembangan hipotesis. Pada bagian tiga, paper ini membahas tentang metode penelitian. Bagian empat dari paper ini menjelaskan tentang hasil penelitian. Terakhir, bagian lima adalah penutup yang menjelaskan tentang simpulan, keterbatasan, dan saran untuk studi berikutnya.

\section{Teori Akuntansi Positif}

Teori akuntansi positif berlandaskan pada teori keagenan. Watts dan Zimmerman (1986) menggunakan teori keagenan untuk menjelaskan dan memprediksi perilaku manajemen untuk memilih prosedur-prosedur akuntansi untuk tujuan tertentu. Ada tiga hipotesis dalam teori akuntansi positif yaitu (1) rencana bonus, (2) perjanjian utang, dan (3) kos politik.

\section{Manajemen Laba}

Schipper (1989) mendefinisikan manajemen laba suatu intervensi dengan tujuan tertentu dalam proses pelaporan keuangan dengan tujuan menghasilkan beberapa keuntungan pribadi. Menurut Xu et al. (2007), definisi Schipper (1989) menegaskan bahwa manajemen laba dapat terjadi dalam bagian proses pengungkapan eksternal dan dapat dalam bentuk angka-angka. Sedikit perhatian dalam definisi ini tentang manajemen laba riil terkait dengan waktu investasi atau keputusan pendanaan untuk mempengaruhi laba yang dilaporkan.

Menurut Healy dan Wahlen (1999), manajemen laba terjadi ketika manajer menggunakan judgment dalam pelaporan keuangan dan pengaturan transaksi-transaksi untuk mengubah laporan-laporan keuangan untuk menyesatkan beberapa stakeholder tentang kinerja keuangan utama perusahaan atau untuk mempengaruhi hasil kontrak yang tergantung pada angka-angka laporan akuntansi. Menurut Xu et al. (2007), definisi Healy dan Wahlen (1999) menegaskan bahwa manajemen laba akrual terjadi ketika manajemen memanipulasi laporan laba dengan mengeksploitasi diskresi akuntansi yang diperkenankan oleh prinsip-prinsip akuntansi berterima umum. Sebaliknya, manajemen laba riil mencakup usaha-usaha manajemen untuk mempengaruhi laporan laba dengan penyesuaian waktu dan ukuran atau skala aktivitias bisnis yang mendasarinya. Menurut Scott (2006), manajemen laba adalah pemilihan kebijakan akuntansi oleh manajer untuk mencapai beberapa tujuan tertentu.

\section{Manipulasi Aktivitas Riil}

Manipulasi aktivitas riil dapat menurunkan nilai perusahaan karena aktivitas ini memiliki efek negatif pada periode berikutnya. Potongan harga yang agresif meningkatkan volume penjualan yang disebabkan oleh harapan pelanggan untuk mendapatkan diskon di periode yang akan datang. Volume yang meningkat menyebabkan produksi yang berlebihan. Ini menyebabkan ke- 
lebihan persediaan yang harus dijual pada periode berikutnya. Ini menyebabkan biaya penyimpanan persediaan menjadi besar. Menurut Roychowdury (2006), manajer tidak tertarik hanya menggunakan menggunakan akrual untuk mengatur laba. Karena, auditor lebih mudah untuk mengetahui akrual ini. Dengan demikian, akan lebih berisiko jika manajer hanya menggunakan akrual untuk mengatur laba. Laba harus diatur untuk memenuhi level laba yang diinginkan. Kondisi ini mendorong manajer untuk mengatur laba melalui aktivitas riil.

Manipulasi aktivitas riil merupakan kegiatan-kegiatan manajemen laba yang menyimpang dari praktik bisnis normal dengan tujuan utama untuk memenuhi batas laba tertentu (Roychowdhury, 2006). Kegiatan manipulasi aktivitas riil dimulai dari praktik operasional yang normal. Ini dilakukan oleh manajemen karena untuk memberi informasi kepada stakeholders bahwa tujuan perusahaan terpenuhi dalam operasi normal. Tindakan ini tidak memberi kontribusi nilai pada perusahaan. Manipulasi aktivitas riil seperti diskon harga dan pengurangan biaya diskresioner dilakukan oleh manajer untuk tujuan-tujuan tertentu. Roychowdhury (2006) menjelaskan bahwa ada tiga cara yang digunakan oleh para pihak manajemen untuk memanipulasi kegiatan operasi perusahaan yaitu manajemen penjualan, overproduction, dan pengurangan biaya diskresi. Manajemen penjualan dilakukan dengan memberikan diskon atau pemberian waktu kredit yang longgar agar dapat menaikkan penjualan selama periode akuntansi supaya dapat memenuhi target laba. Sebagai contoh manajer melakukan tambahan penjualan atau mempercepat penjualan dari periode mendatang ke periode sekarang dengan cara menawarkan potongan harga yang terbatas. Praktik ini menyebabkan volume penjualan meningkat dan menyebabkan laba tahun berjalan tinggi. Akan tetapi, aliran kas menjadi turun akibat penjualan kredit dan potongan harga. Ini menyebabkan aliran kas operasi periode sekarang menurun dibanding tingkat penjualan normal.

Cara berikutnya adalah melakukan produksi secaara besar-besaran (overproduction) untuk memenuhi kebijakan penjualan diskon. Manajemen perusahaan manufaktur dapat melakukan produksi lebih banyak dibanding yang dibutuhkan dengan tujuan untuk mencapai permintaan sehingga laba yang diharapkan dapat meningkat sesuai dengan laba yang ditargetkan. Produksi dalam jumlah yang besar menyebabkan biaya overhead tetap dibagi dengan jumlah unit barang yang besar sehingga biaya per unit dan beban pokok penjualan menurun. Penurunan beban ini berpengaruh pada margin operasi. Akibat lain penurunan beban pokok per unit barang yang diproduksi secara besar-besaran adalah aliran kas operasi menjadi lebih rendah dibanding tingkat penjualan normal. Pengurangan biaya diskresi merupakan cara untuk menghindari melaporkan laba negatif. Biaya diskresi yang dapat dikurangi seperti biaya penjualan, biaya iklan, administrasi, dan biaya penelitian dan pengembangan. Pada akhir periode, pengurangan biaya ini menyebabkan rekening hutang berkurang dan akrual abnormal yang positif.

Cohen et al. (2008) menginvestigasi aktivitas manajemen laba baik akrual dan riil dalam periode Sarbanes-Oxley (SOX) untuk mengetahui manajemen sebelum dan setelah SOX. Cohen et al. (2008) menemukan bahwa sebelum periode SOX manajemen laba akrual meningkat dan manajemen laba riil menurun. Akan tetapi, pada periode setelah SOX manajemen laba akrual menurun secara signifikan dan manajemen laba riil meningkat secara signifikan.

Di Indonesia, Oktarina dan Hutagaol (2009) menganalisis aktivitas aliran kas untuk mendeteksi manipulasi aktivitas riil dan dampaknya pada kinerja pasar. Mereka menggunakan aktivitas aliran kas untuk mendeteksi operasi abnormal aktivitas riil. Oktarina dan Hutagaol (2009) menemukan bahwa manajer perusahaan memanipulasi aktivitas riil melalui aliran kas operasi yang berdampak pada kinerja pasar.

\section{Auditor Eksternal dan Manajemen Laba}

Sanjaya (2008) menemukan bahwa ada perbedaan signifikan manajemen laba antara perusahaan yang diaudit oleh kantor akuntan publik yang berafiliasi dengan big four dan perusahaan yang diaudit oleh kantor akuntan publik yang tidak berafiliasi dengan big four (non big four). Auditor big four akan berusaha secara sungguhsungguh untuk mempertahankan reputasinya termasuk kantor akuntan publik yang berafiliasi dengannya.

Rusmin (2010) menemukan bahwa ada hubungan negatif antara auditor spesialisasi industri dan nilai absolut akrual diskresioner. Hasil ini menegaskan bahwa auditor spesialisasi dapat membatasi dan mendeteksi praktik manajemen laba oleh manajemen perusahaan. Analisis menunjukkan bahwa hubungan antara ukuran kualitas auditor dan manajemen laba hanya signifikan bagi kantor akuntan publik big four. Chi et al. (2011) menguji hubungan antara kualitas audit dan manajemen laba riil. Chi et al. (2011) menemukan bahwa kantor akuntan publik big four dapat mengurangi praktik manajemen laba riil. Ini ditunjukkan dengan aliran kas abnormal yang lebih rendah. 
Inaam et al. (2012) menegaskan bahwa auditor yang memiliki spesialisasi industri mempresentasikan suatu dimensi penting dari kualitas audit. Auditor yang memiliki spesialisasi industri menunjukkan suatu dimensi penting kualitas audit. Pengetahuan industri dari seorang spesialisasi dikembangkan melalui perluasan pengalaman audit, pelatihan staf spesialisasian, dan investasi-investasi dalam teknologi informasi. Relatif terhadap auditor non spesialiasi, pengetahuan tentang industri membantu auditor spesialisasi untuk memberi pelayanan audit yang lebih tinggi kepada klien dengan membatasi perilaku diskresioner dari manajemen. Kemudian, spesialisasi industri adalah suatu cara penting yang mana kantor akuntan publik dapat membedakan diri dari para pesaingnya.

Chiang dan Lin (2012) menguji faktor-faktor yang mendorong penerbitan opini negatif atas laporan tengah tahunan sementara penerbitan opini positif dalam laporan tahunan dari perspektif hubungan auditor klien di perusahaan-perusahaan yang terdaftar di Taiwan. Hasil penelitian menunjukkan bahwa auditor yang memiliki spesialisasi industri memiliki pengaruh yang negatif dan signifikan. Hasil ini menegaskan bahwa auditor ini dapat melakukan judgment professional dan memiliki perbedaan yang sangat kecil antara opini dalam laporan tengah tahunan dan laporan tahunan.

Untuk menjaga reputasi, auditor big four bekerja secara lehih cermat dengan spesifikasispesifikasi yang dimilikinya. Kecermatan dan pengalaman ini diduga dapat mencegah praktik manipulasi laba dengan aktivitas riil. Hipotesis penelitian ini adalah sebagai berikut.

$\mathrm{H}_{1}$ : Kantor akuntan publik yang berafiliasi dengan big four berpengaruh negatif terhadap manipulasi aktivitas riil (manajemen laba riil).

\section{METODE PENELITIAN}

\section{Sampel}

Sampel dalam penelitian ini adalah perusahaan manufaktur yang terdaftar di Bursa Efek Indonesia yang terdaftar selama periode 20082011. Teknik yang digunakan untuk memilih sampel adalah purposive sampling dengan telah terdaftar di Bursa Efek Indonesia 1 Januari 2008, menerbitkan laporan tahunan pada tahun 2008 2011, dan memiliki akhir periode 31 Desember. Jumlah observasi selama periode 2008-2011 adalah 307. Akan tetapi, setelah dilakukan pengujian normalitas ada beberapa outlier yang mengganggu distribusi data. Ada 21 observasi yang harus dihilangkan sehingga jumlah observasi yang layak untuk diolah adalah 286 .

\section{Definisi dan Pengukuran Variabel}

Manipulasi aktivitas riil adalah variabel dependen. Manipulasi aktivitas riil dapat dideteksi dengan tiga cara yaitu melihat dari aliran kas operasi, biaya produksi, dan biaya diskresioner. Oleh karena itu, penelitian variabel dependen menggunakan model pengukuran Roychowdhury (2006) yaitu Cash Flow Operation (CFO), discretionary expense dan production costs dengan menggunakan model regresi.

Variabel ini diukur dengan aliran kas operasi abnormal. Aliran kas ini merupakan hasil dari aliran kas operasi sesungguhnya dikurangi dengan aliran kas operasi ekspektasian (normal). Aliran kas operasi aktual dapat dibagi dengan total aktiva satu tahun sebelum pengujian $\left(\frac{C F O_{t}}{A_{t-1}}\right)$. Aliran kas operasi normal dapat dihitung dengan menggunakan koefisien estimasi dari model persamaan $\left(\alpha_{0}+\alpha_{1}\left(\frac{1}{A_{t-1}}\right)+\beta_{1}\left(\frac{S_{t}}{A_{t-1}}\right)+\beta_{2}\left(\frac{\Delta S_{t}}{A_{t-1}}\right)\right) . \quad$ Model regresi aliran kas operasi adalah sebagai berikut. $\frac{C F O_{t}}{A_{t-1}}=\alpha_{0}+\alpha_{1}\left(\frac{1}{A_{t-1}}\right)+\beta_{1}\left(\frac{S_{t}}{A_{t-1}}\right)+\beta_{2}\left(\frac{\Delta S_{t}}{A_{t-1}}\right)+e_{t}$

Keterangan:

$\mathrm{CFO}_{t}$ : aliran kas operasi pada tahun $\mathrm{t}$

$A_{t-1}$ : total aktiva pada tahun t-1

$S_{t} \quad$ : penjualan pada tahun $\mathrm{t}$

$\Delta S_{t}$ : penjualan pada tahun t dikurangi penjualan pada tahun $\mathrm{t}-1$

$\alpha_{0}:$ konstanta

$e_{t} \quad$ :error term pada tahun $\mathrm{t}$

Biaya produksi abnormal merupakan hasil biaya produksi aktual dikurangi dengan biaya produksi normal. Biaya produksi aktual dibagi dengan total aktiva satu tahun sebelum periode pengujian $\left(\frac{P R O D_{t}}{A_{t-1}}\right)$. Biaya produksi normal dapat dihitung dengan menggunakan koefisien estimasi dari model persamaan $\left(\alpha_{0}+\alpha_{1}\left(\frac{1}{A_{t-1}}\right)+\beta_{1}\left(\frac{S_{t}}{A_{t-1}}\right)+\right.$ $\beta_{2}\left(\frac{\Delta S_{t}}{A_{t-1}}\right)+\beta_{3}\left(\frac{\Delta S_{t-1}}{A_{t-1}}\right)$ ). Model regresi untuk biaya produksi adalah sebagai berikut.

$$
\begin{aligned}
\frac{P R O D_{t}}{A_{t-1}}=\alpha_{0}+\alpha_{1} & \left(\frac{1}{A_{t-1}}\right)+\beta_{1}\left(\frac{S_{t}}{A_{t-1}}\right)+\beta_{2}\left(\frac{\Delta S_{t}}{A_{t-1}}\right) \\
& +\beta_{3}\left(\frac{\Delta S_{t-1}}{A_{t-1}}\right)+e_{t}
\end{aligned}
$$

Keterangan:

$P R O D_{t}$ : biaya produksi pada tahun t, $P R O D_{t}=$ $\mathrm{COGS}_{t}+\Delta I N V_{t}$

$A_{t-1} \quad$ : total aktiva pada tahun t-1

$S_{t} \quad$ : penjualan pada tahun $\mathrm{t}$

$\Delta S_{t} \quad$ : penjualan pada tahun t dikurangi penjualan pada tahun t-1

$\Delta S_{t-1}$ : perubahan penjualan pada tahun $\mathrm{t}-1$

$\alpha_{0} \quad$ : konstanta

$e_{t} \quad:$ error term pada tahun $\mathrm{t}$ 
Biaya diskresioner abnormal diperoleh dengan cara mengurangkan nilai biaya diskresioner aktual dengan biaya diskresioner normal. Biaya diskresioner aktual dibagi dengan total aktiva satu tahun sebelum periode pengujian $\left(\frac{\text { DISEXPt }_{t}}{A_{t-1}}\right)$. Biaya diskresioner normal dapat dihitung dengan menggunakan koefisien estimasi dari model $\alpha_{0}+$ $\alpha_{1}\left(\frac{1}{A_{t-1}}\right)+\beta\left(\frac{S_{t}}{A_{t-1}}\right)$. Biaya diskresioner didefinisikan sebagai jumlah biaya iklan, biaya riset dan pengembangan, biaya penjualan, dan administrasi dan umum. Nilai koefisien estimasi dari persamaan regresi di atas digunakan untuk menghitung nilai biaya diskresioner normal. Untuk menghitung tingkat normal biaya diskresioner peneliti menggunakan model regresi berikut yang mereplikasi dari penelitian Roychowdhury (2006):

$$
\frac{\operatorname{DISEXP}_{t}}{A_{t-1}}=\alpha_{0}+\alpha_{1}\left(\frac{1}{A_{t-1}}\right)+\beta\left(\frac{S_{t}}{A_{t-1}}\right)+e_{t}
$$

Keterangan:

$\operatorname{DISEXP}_{t}$ : biaya diskresioner pada tahun $\mathrm{t}$

$A_{t-1} \quad$ : total aktiva pada tahun t-1

$S_{t} \quad:$ penjualan ada tahun $\mathrm{t}$

$\alpha_{0} \quad:$ konstanta

$e_{t} \quad$ : error term pada tahun $\mathrm{t}$

Variabel independen dalam penelitian ini adalah kualitas audit. Variabel ini dinilai menggunakan skala nominal. 1 adalah untuk perusahaan manufaktur yang diaudit oleh kantor akuntan publik yang berafiliasi dengan big four. 0 adalah untuk perusahaan manufaktur yang diaudit oleh kantor akuntan publik yang tidak berafiliasi dengan big four (non big four). Big four yaitu Ernest and Young, KPMG, Deloitte Touche \& Tohmatsu, dan Pricewaterhouse Coopers.

Dalam penelitian ini, ada dua variabel kontrol yaitu leverage dan size perusahaan. Leverage diukur dengan debt to equity ratio. Size perusahaan diukur sebagai logaritma dari total aktiva.

\section{HASIL DAN PEMBAHASAN}

Berdasarkan hasil di Tabel 1, nilai minimum variabel aliran kas operasi abnormal (OCF) adalah -1,57 dan nilai maksimum CFO adalah 0,48. Nilai mean CFO adalah -0,3959 dan deviasi standar adalah 0,2769. Nilai minimum variabel produksi abnormal (PROD) adalah -0,94 dan nilai maksimum PROD adalah 0,75. Nilai mean PROD adalah -0,0705 dan deviasi standar adalah 0,2300. Nilai minimum variabel biaya diskresioner abnormal (DISEXP) adalah -4,04 dan nilai maksimum DISEXP adalah -0,03. Nilai mean DISEXP adalah $-1,2424$ dan deviasi standar adalah 0,6245. Nilai minimum variabel Leverage adalah -27,05 dan nilai maksimum Leverage adalah 216,26. Nilai mean Leverage adalah 2,2219 dan deviasi standar adalah 13,3495. Nilai minimum variabel Size adalah 21,84 dan nilai maksimum Size adalah 32,66. Nilai mean Size adalah 27,9174 dan deviasi standar adalah 1,7232 .

Tabel 1. Statistik Deskriptif

\begin{tabular}{lrrrrr}
\hline & N & $\begin{array}{c}\text { Mini- } \\
\text { mum }\end{array}$ & $\begin{array}{c}\text { Maxi- } \\
\text { mum }\end{array}$ & Mean & $\begin{array}{c}\text { Std. } \\
\text { Deviation }\end{array}$ \\
\hline CFO & 286 & $-1,57$ & 0,48 & $-0,3959$ & 0,27688 \\
PROD & 286 & $-0,94$ & 0,75 & $-0,0705$ & 0,22995 \\
DISEXP & 286 & $-4,04$ & $-0,03$ & $-1,2424$ & 0,62448 \\
Leverage & 286 & $-27,05$ & 216,26 & 2,2219 & 13,34949 \\
Size & 286 & 21,84 & 32,66 & 27,9174 & 1,72326 \\
Kualitas audit & 286 & .00 & 1,00 & 0,5070 & 0,50083 \\
Valid N (listwise) & 286 & & & & \\
\hline
\end{tabular}

Berdasarkan hasil di Tabel 2, kualitas audit tidak mampu mengurangi praktik manajemen laba yang dilakukan dengan memberi beberapa kebijakan diskon atau kemudahan lainnya. Kebijakan ini dilakukan oleh manajemen untuk meningkatkan penjualan sesuai dengan dengan yang ditargetkan agar target laba yang dikehendaki dapat tercapai. Ketika auditor melakukan audit dan menemukan jumlah transaksi penjualan yang meningkat secara drastis, auditor hanya mampu memberi catatan kepada manajemen perusahaan bahwa ada kenaikan penjualan yang tidak normal. Auditor tidak akan menggunakan informasi ini untuk mempengaruhi opini audit karena praktik kebijakan penjualan seperti ini adalah aktivitas normal. Padahal, manajemen melakukan kebijakan ini untuk tujuan-tujuan tertentu. Hal ini juga terjadi pada perusahaan publik sebut saja PT A Tbk. Manajer perusahaan ini melakukan kebijakan penjualan dengan berbagai program kemudahan kredit dan pembayaran. Ini adalah praktik yang dilakukan oleh manajer perusahaan untuk memuhi target laba perusahaan agar mereka tetap mendapatkan bonus.

Seperti argumentasi yang dikemukan oleh Roychowdury (2006) bahwa akrual lebih berisiko dibanding dengan manajemen laba riil. Auditor lebih mudah untuk mengetahui akrual ini. Hasil penelitian ini konsisten dengan hasil penelitian yang dilakukan oleh Inaam et al. (2012) yang menemukan bahwa auditor berkualitas tidak mampu mencegah praktik manajemen aktivitas riil. Ini kemungkinan auditor tidak dapat memainkan perannya untuk mengurangi manipulasi aktivitas riil karena manipulasi ini lebih sulit bagi auditor eksternal, regulator, dan stakeholder lain untuk mendeteksi manipulasi aktivitas riil dibanding manajemen laba akrual. 
Tabel 2. Hasil Pengujian Hipotesis

Model 1: $O C F_{i t}=\alpha+\beta_{1}$ Kualitas Audit $_{i t}+\beta_{2}$ Leverage $_{i t}+$ $\beta_{4}$ Size $_{i t}+\varepsilon_{i t}$

\begin{tabular}{lrrr}
\hline \multicolumn{1}{c}{ Variabel } & Koefisien & t-statistik & \multicolumn{1}{c}{ Nilai-p } \\
\hline Constant & $-0,930$ & $-3,222$ & $0,001^{* * *}$ \\
Kualitas Audit & $-0,051$ & $-1,397$ & 0,163 \\
Leverage & 0,001 & 0,339 & 0,735 \\
Size & 0,020 & 1,889 & $0,060^{* * *}$
\end{tabular}

$\begin{array}{lr}\text { Adjusted } R^{2} & 0,004 \\ \text { F-statistik } & 1,387 \\ \text { Probabilitas F-statistik } & 0,247 \\ \text { N } & 286\end{array}$

Keterangan:

$* * *, * *, *=$ secara statistis signifikan masing-masing pada tingkat signifikansi 0,$01 ; 0,05$; dan 0,1 berdasarkan pengujian satu sisi.

Berdasarkan hasil di Tabel 3, kualitas audit mampu mengurangi praktik manajemen laba yang dilakukan dengan produksi abnormal. Hasil ini menegaskan bahwa hipotesis penelitian ini terdukung. Hasil penelitian ini konsisten dengan temuan Sanjaya (2008), Rusmin (2010), Chi et al. (2011) yang mendokumentasikan bahwa kualitas audit dapat mencegah atau mendeteksi manajemen laba. Secara khusus, Chi et al. (2011) menemukan akuntan publik big four dapat mengurangi praktik manajemen laba riil.

Tabel 3. Hasil Pengujian Hipotesis

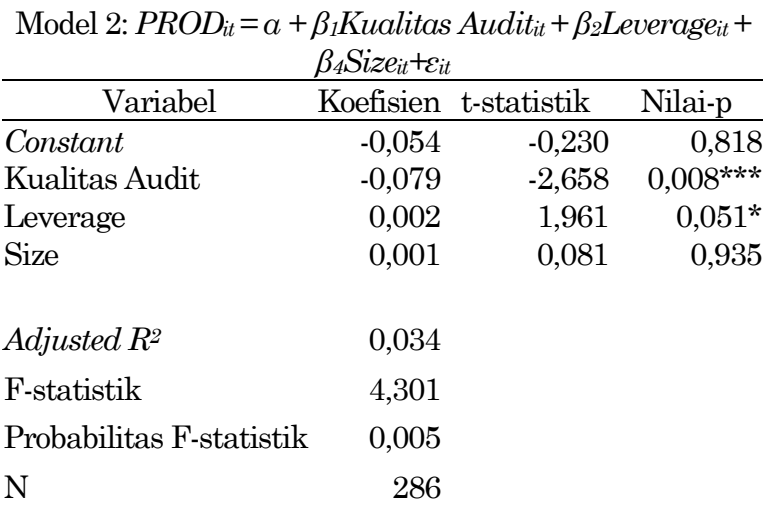

Keterangan:

$* * *, * *, *=$ secara statistis signifikan masing-masing pada tingkat signifikansi 0,$01 ; 0,05$; dan 0,1 berdasarkan pengujian satu sisi.

Hasil yang sama juga terjadi di Tabel 4 yang menunjukkan bahwa auditor berkualitas berpengaruh negatif terhadap beban diskresioner. Ini ditunjukkan oleh nilai koefisien kualitas audit 1,400 yang signifikan pada alfa $5 \%$. Berdasarkan hasil ini, hipotesis yang menyatakan kantor akuntan publik yang berafiliasi dengan big four berpengaruh negatif terhadap manipulasi aktivitas riil didukung.
Tabel 4. Hasil Pengujian Hipotesis

Model 3: DISEXP $_{i t}=\alpha+\beta_{1}$ Kualitas Audit $_{i t}+\beta_{2}$ Leverage $_{i t}$ $+\beta_{4}$ Sizeit $_{i t}+\varepsilon_{i t}$

\begin{tabular}{lrrr}
\hline \multicolumn{1}{r}{ Variabel } & Koefisien & t-statistik & \multicolumn{1}{c}{ Nilai-p } \\
\hline Constant & $-1,400$ & $-2,161$ & $0,032^{* *}$ \\
Kualitas Audit & $-0,194$ & $-2,363$ & $0,019^{* *}$ \\
Leverage & 0,002 & 0,865 & 0,388 \\
Size & 0,009 & 0,377 & 0,706
\end{tabular}

Adjusted $R^{2} \quad 0,014$

F-statistik 2,368

Probabilitas F-statistik $\quad 0,071$

$\mathrm{N} \quad 286$

Keterangan:

$* * *, * *, *=$ secara statistis signifikan masing-masing pada tingkat signifikansi 0,$01 ; 0,05$; dan 0,1 berdasarkan pengujian satu sisi.

Hasil ini mendukung argumentasi yang dikemukan oleh Jensen dan Meckling (1976) bahwa auditor memiliki suatu peran penting untuk mengurangi konflik kepentingan antara manajer dan para pemegang saham. Pengauditan merupakan suatu sarana pemonitoran bagi para pemegang saham karena auditor akan melaporkan salah saji material yang dapat dideteksi dalam laporan keuangan auditan.

\section{KESIMPULAN DAN SARAN}

Kualitas auditor yang diproksikan dengan kantor akuntan publik yang berafiliasi dengan big four mampu mencegah dan mendeteksi manajemen laba riil atau manipulasi aktivitas riil. Manipulasi aktivitas riil ini merupakan bentuk manajemen laba yang buruk atau oportunistik. Keberadaan auditor berkualitas dapat melaksanakan perannya sebagai pemonitor untuk melindungi kepentingan publik. Hal ini merupakan sesuatu yang sangat penting untuk dilakukan karena ini adalah upaya auditor untuk menjaga citranya setelah merasa terpukul oleh perilaku kantor akuntan publik Arthur Anderson dalam kasus Enron.

Akan tetapi, dalam penelitian ini auditor tidak dapat mencegah praktik manipulasi aktivitas riil yang dilakukan melalui kebijakan penjualan dengan memberi beberapa kemudahan dalam program penjualan. Hal ini disebabkan karena auditor tidak dapat menjalankan perannya sebagai pemonitor untuk mengurangi manipulasi aktivitas riil. Karena manipulasi aktivitas riil lebih sulit untuk didekteksi oleh auditor eksternal, regulator, dan stakeholder dibandingkan dengan manajemen laba akrual (Inaam et al., 2012).

Saran untuk penelitian berikutnya adalah dengan memasukkan komite audit dan komisaris independen dalam penelitian. Ini perlu dilakukan 
untuk mengidentifikasi apakah lembaga ini mampu mengurangi praktik-praktik kotor yang dilakukan oleh manajemen perusahaan. Selain itu, dua lembaga ini adalah bentukan perusahaan dalam usaha menerapkan tata kelola perusahaan. Dua lembaga ini mendapatkan fasilitas baik remunerasi dan lainnya dari perusahaan. Ini adalah dana dari shareholders. Penelitian ini berikutnya juga dapat dilakukan dengan mempertimbangkan pengungkapan sukarela yang dilakukan oleh perusahaan.

\section{DAFTAR PUSTAKA}

Chi, W., Lisic, L.L., dan Pevzner, M. (2011). Is enhanced audit quality associated with greater real earnings management? Accounting Horizons, 25, 315-335.

Chiang, H.T. dan Lin, S.L. (2012). Effect of auditor's judgment and specialization on their differential opinion between semiannual and annual financial reports. Global Journal of Business Research, 6, 1-22.

Cohen, D.A., Dey, A., dan Lys, T.Z. (2008). Real and accrual-based earnings management in the pre-and post-Sarbanes-Oxley periods. The Accounting Review, 83, 757-787.

FASB. (2010). Statement of Financial Accounting Concepts No. 8: Conceptual Framework for Financial Reporting, a replacement of FASB Concepts Statements No. 1 and No. 2. Financial Accounting Standards Board of the Financial Accounting Foundation.

Healy, P.M. dan Wahlen, J.M. (1999). A review of the earnings management literature and its implications for standard setting. Accounting Horizon, 13, 365-383.

Inaam, Z., Khmnoussi, H., dan Fatma, Z. (2012). Audit quality and earnings management in Tunisian context. International Journal of Accounting and Financial Reporting, 2, 17-33.
Jensen, M.C. dan Meckling, W.H. (1976). “Theory of the Firm: Managerial Behavior, Agency Costs and Ownership Structure". Journal of Financial Economics, 3, 305-360.

Oktarina, M., dan Hutagaol, Y. (2009). Analisis arus kas kegiatan operasi dalam mendeteksi manipulasi aktivitas riil dan dampaknya terhadap kinerja pasar. Jurnal Riset Akuntansi Indonesia, 12, 1-14.

Roychowdhury, S. (2006). Earnings management through real activities manipulation. Journal of Accounting and Economics, 42, 335-370.

Ratmono, D. (2011). Real and accrual-based earnings management: can a qualified auditor detect it? Indonesian Journal of Accounting Research, 7(1), 92-109.

Rusmin, R. (2010). Auditor quality and earnings management: Singaporean evidence. Managerial Auditing Journal, 25, 618-638.

Sanjaya, I.P.S. (2008). Auditor eksternal, komite audit, dan manajemen laba. Jurnal Riset Akuntansi Indonesia, 11, 97-116.

Sanjaya, I.P.S. dan Saragih, M.F. (2012). The effect of real activities manipulation on accrual earnings management: the case in Indonesia Stock Exchange. Journal of Modern Accounting and Auditing, 8, 1291-1300.

Schipper, K. (1989). Commentary on earnings management. Accounting Horizons, 3: 91-102.

Scott, W.R. (2006). Financial accounting theory (4th ed.). Scarborough, Ontario: Prentice-Hall Canada, Inc.

Watts, R.L. dan Zimmerman, J.L. (1986). Positive accounting theory, Englewood Cliefs, New Jersey: Prentice-Hall., Inc.

Xu, R.Z., Taylor, G.K. dan Dugan, M.T. (2007). Review of real earnings management literature. Journal of Accounting Literature, 26, 195-228. 